DOI: https://10.15407/kvt198.04.062

UDC 615.47: 004.9

VOVK M.I., PhD (Biology), Senior Researcher, Head of Bioelectrical Control \& Medical Cybernetics Department e-mail: vovk@irtc.org.ua; imvovk3940@gmail.com

KUTSYAK O.A., PhD (Engineering),

Senior Researcher of the Bioelectrical Control \& Medical

Cybernetics Department

e-mail: spirotech85@ukr.net

International Research and Training Center for Information

Technologies and Systems of the National Academy of Sciences

of Ukraine and of Ministry of Education and Science of Ukraine, 40, Acad. Glushkov av., Kyiv, 03187, Ukraine

\title{
SOFTWARE MODULE FOR PERSONAL DIAGNOSTICS OF MOTOR FUNCTIONS AFTER STROKE
}

Introduction. Diagnostics of motor functions after stroke plays an important role in the formation of a rehabilitation program. The results of the preliminary clinical trials of our proposed technique for quantitative assessment of motor functions deficit during studying the dynamics of movement restoring based on bio-informational technology of motor control TRENAR ${ }^{\circledR}$ confirmed the advisability of using this technique to create a new algorithmic and software tools for personal diagnostics of motor functions.

The purpose of the paper is to develop a specialized module for the personal diagnostics of motor functions in patients after stroke, which software implements the determination of the degree of motor functions disorders and the results of their recovery using the technique for quantitative assessment of motor functions deficit.

Results. The structural and functional model of the software module for personal diagnostics of motor functions and the effectiveness of their recovery as a result of rehabilitation measures in patients after stroke has been developed.

An algorithm for diagnostic the motor functions disorder degree of the affected limbs in patients after stroke and the activity diagram of software module using Unified Modeling Language (UML) are presented.

The software module "Movement Test Stroke" has been made in Visual Studio 2013 software environment. The programming language is $C \#$. The module is installed in the PC structure.

Diagnostic benefits: the ability to obtain an integrated quantitative assessment of the motor functions deficit of the upper and lower limb at the level of separate joints, hand or walking according to relevant evidential criteria, and assessment of muscle hyper- or hypotone at different stages of rehabilitation. The advantage of diagnostics is that the motor func- 
tions disorder degree is performed relative to the patient's own healthy limbs, the motor functions of which characterize the individual norm of disorders absence.

Conclusions. The quantitative assessment of motor function deficit by evidential criteria, which is provided by the software module "Movement Test Stroke" is the basis to synthesize the digital health mobile means for information and advisory assistance to the physician in creating and making adjustments to personal plan for recovery the motor functions affected by pathology at different stages of stroke rehabilitation.

Keywords: software module, structural and functional model, diagnostics, algorithm, motor functions, personal quantitative assessment, stroke.

\section{INTRODUCTION}

For many years, stroke has been ranked $2^{\text {nd }}$ in the list of major causes of disability and death in the world and in Ukraine. Stroke is one of the most common causes of functional failure. This disease may cause impairment or loss of motor functions, vision, speech and mental functions. Of particular concern is the increasing burden of stroke among people of working age: more than $50 \%$ of those who survived stroke never return to work. In Europe, an action plan to combat stroke during 2018-2030 has been approved. [1]. In Ukraine the creation of modern centers for the treatment of strokes according to European standards is also provided.

The main goal of the rehabilitation process is associated with person's reserves mobilization that is adequate to his state to restore damaged or lost functions. When restoring motor functions, the mobilization of reserves provides for the development and implementation of individual comprehensive programs of medical rehabilitation, in which along with drugs, electrical myoneurostimulation especially programmed stimulation occupies a significant place, as a way to force muscle contraction according to certain programs. To determine the control action - an individual program for the rehabilitation of motor functions the rehabilitologist should have a wide range of training programs and methods, among which he can choose the one that is most appropriate for the state and stage of patient rehabilitation. This approach allows the implementation of a new bioinformation technology for the restoration of motor functions TRENAR ${ }^{\circledR}$, which is realized by portable electronic devices Trenar-01 and Trenar-02 [2].

The range of programs in these devices is represented for training the forced muscle contractions: 1) by synthesized electromyostimulation programs - the program "SYNTHESIS"; 2) by programs that are "read" from the patient's own healthy muscles or muscles of another person (instructor) during their voluntary contractions and transmitted to the training muscles online - the program "DONOR"; 3) for training the ratio of voluntary and forced contractions of the muscles under the threshold electromyostimulation method, when voluntary, even minor, contractions of the training muscles, under the condition of overcoming a certain threshold of the EMG signal, automatically "start" the electrostimulation of the same muscle to achieve a certain value of muscle contraction - the program "THRESHOLD"; 4) for training voluntary and forced muscles contractions in recording-reproducing mode, when EMG signal of arbitrarily contracted muscle is recorded in the memory of device and transformed into electrical stimulation program of the same muscle that is being trained - the program "MEMORY-Auto"; 5) for training voluntary muscles contractions by the BIOFEEDBACK method (visual and auditory) by electromyogram - the program "BIOTRAINING" [2, 3]. 
A common benefit of these training programs is the combination of physical and cognitive effects that trigger and stimulate the person's reserves to restore movements. However, each program has personal advantages that determine the feasibility of its use, depending on the state of motor functions, the general neurological status of the patient and the stage of rehabilitation.

\section{PROBLEM STATEMENT}

The use of technology TRENAR $^{\circledR}$ in restorative motion therapy has shown a significant percentage of improvements in locomotor functions, which in particular, after stroke, reaches $93 \%$. These results provide the basis for incorporation the technology TRENAR $^{\circledR}$ into the mandatory set of measures aimed at restoring motor functions. However, the success of the extensive use of innovative technology TRENAR $^{\circledR}$ is largely determined by the objective evaluation of the effectiveness of the rehabilitation process based on the quantitative assessment of the motor function disorder degree of patient at different recovery periods after stroke.

As a result of previous studies, a new technique for quantitative assessment of motor functions deficit (motor disorders depth) in patients after stroke has been developed. This technique is based on expert evaluation according to the main and additional evidential criteria [4]. The main features of the technique are:

- a separate quantitative assessment of the motor functions deficit of the affected lower and upper limbs, their proximal and distal departments, according to the main criteria, on the basis of which an integral quantitative assessment of global movements disorders is formed;

- introduction of additional criteria for hand assessing (including fine motor skills) and form of walking;

- determination of the individual norm of disorders absence: expert assessing of the affected limbs is carried out in relation to the patient's own healthy limbs, the motor functions of which characterize the individual norm of disorders absence;

- unification of quantitative assessment of the disorders degree: all quantitative scales for all criteria have the same six-point gradation.

The developed technique has undergone preliminary clinical testing during studies of the dynamics of movement restoration after stroke with the new technology of training / restoration of movement functions TRENAR ${ }^{\circledR}$. The results of the trial confirmed the benefits of the technique and appropriateness of its use in clinical practice.

The purpose of the paper is to develop a specialized module for the personal diagnosis of motor functions in patients after a stroke, which software implements the determination of the degree of motor functions impairment and the results of their recovery using the new method of personal quantitative assessment of motor function deficiency.

\section{STRUCTURAL AND FUNCTIONAL MODEL OF THE SOFTWARE MODULE FOR THE DIAGNOSTICS THE DEGREE OF MOTOR FUNCTIONS DISORDERS IN PATIENTS AFTER STROKE}

The Protocol with the relevant tables for assessing the motor disorders for the convenience of using by neurologists a new technique for quantitative assessment of movement disorders degree in patients after stroke by TRENAR ${ }^{\circledR}$ technology has been developed: 
Table. 1. The muscle strength and movements' volume assessing

\begin{tabular}{|c|l|c|l|}
\hline Grade & $\begin{array}{c}\text { The muscle strength of } \\
\text { the affected limb }\end{array}$ & $\begin{array}{c}\text { Ratio (affected / } \\
\text { healthy mus- } \\
\text { cle), } \%\end{array}$ & \multicolumn{1}{c|}{$\begin{array}{c}\text { Movements' volume refer- } \\
\text { ence }\end{array}$} \\
\hline $\mathbf{5}$ & $\begin{array}{l}\text { Full motion during gravity } \\
\text { with maximum external } \\
\text { counteraction }\end{array}$ & 100 & $\begin{array}{l}\text { Movements' volume is full, } \\
\text { tempo isn't reduced }\end{array}$ \\
\hline $\mathbf{4}$ & $\begin{array}{l}\text { Full motion during gravity } \\
\text { and with little external } \\
\text { counteraction }\end{array}$ & 75 & $\begin{array}{l}\text { Movements' volume is 75- } \\
100 \% \text { of norm; strength, } \\
\text { agility, tempo are reduced }\end{array}$ \\
\hline $\mathbf{3}$ & $\begin{array}{l}\text { Full motion during gravity } \\
\text { only }\end{array}$ & 50 & $\begin{array}{l}\text { Movements' volume is 50-75\% } \\
\text { of norm, inept }\end{array}$ \\
\hline $\mathbf{2}$ & $\begin{array}{l}\text { Full motion in unloading } \\
\text { conditions }\end{array}$ & $\begin{array}{l}\text { Movements' volume is 25-50\% } \\
\text { of norm }\end{array}$ \\
\hline $\mathbf{1}$ & $\begin{array}{l}\text { A feeling of tension } \\
\text { during the attempt of } \\
\text { voluntary movement }\end{array}$ & $\begin{array}{l}\text { Movements' volume is up to } \\
25 \% \text { of normal, is extremely } \\
\text { restricted }\end{array}$ \\
\hline $\mathbf{0}$ & $\begin{array}{l}\text { Absence of tension signs } \\
\text { during the attempt of } \\
\text { voluntary movement }\end{array}$ & 0 & No active movements \\
\hline
\end{tabular}

Table. 2. The motor functions of the upper and lower limbs by additional criteria assessing

\begin{tabular}{|c|c|c|c|c|}
\hline \multirow{2}{*}{ Grade } & \multicolumn{3}{|c|}{ Upper limb (hand) } & \multirow{2}{*}{$\begin{array}{c}\text { Lower limb (walk- } \\
\text { ing) } \\
\text { Form of walking }\end{array}$} \\
\hline & $\begin{array}{l}\text { Contrasting the } \\
\text { thumb }\end{array}$ & $\begin{array}{c}\text { Flexing of } \\
\text { fingers in fist }\end{array}$ & $\begin{array}{l}\text { The main hand's } \\
\text { motor function }\end{array}$ & \\
\hline 5 & $\begin{array}{c}\text { Reaches the base } \\
\text { of all fingers }\end{array}$ & Full flexing & Function is saved & No change \\
\hline 4 & $\begin{array}{c}\text { Reaches the base } \\
\text { of all fingers } \\
\text { (without holding } \\
\text { the base) }\end{array}$ & $\begin{array}{l}\text { Full flexing } \\
\text { (without hold- } \\
\text { ing) }\end{array}$ & $\begin{array}{l}\text { Capturing and } \\
\text { holding the items } \\
\text { are saved, captur- } \\
\text { ing the small items } \\
\text { is available (with } \\
\text { no hold function) }\end{array}$ & $\begin{array}{l}\text { While walking } \\
\text { limping by the } \\
\text { paretic leg }\end{array}$ \\
\hline 3 & $\begin{array}{l}\text { Reaches the base } \\
\text { of 4-th finger }\end{array}$ & $\begin{array}{c}\text { Slight flexing } \\
\text { limitation of } \\
\text { distal phalanges } \\
\text { to thenar }\end{array}$ & $\begin{array}{l}\text { Holding the items } \\
\text { is available, captur- } \\
\text { ing the small items } \\
\text { is complicated }\end{array}$ & $\begin{array}{l}\text { Hemiparetic walk- } \\
\text { ing } \\
\text { (patient pulls leg) }\end{array}$ \\
\hline 2 & $\begin{array}{l}\text { Reaches the base } \\
\text { of 3-rd finger }\end{array}$ & $\begin{array}{c}\text { Moderate } \\
\text { limitation of } \\
\text { distal phalanges } \\
\text { to thenar }\end{array}$ & $\begin{array}{l}\text { Capturing the large } \\
\text { items without their } \\
\text { long and strong } \\
\text { holding is available }\end{array}$ & $\begin{array}{c}\text { Circulating or } \\
\text { hemiplegic walking }\end{array}$ \\
\hline 1 & $\begin{array}{l}\text { Reaches the base } \\
\text { of 2-nd finger }\end{array}$ & $\begin{array}{c}\text { Significant } \\
\text { limitation of } \\
\text { distal phalanges } \\
\text { to thenar }\end{array}$ & $\begin{array}{c}\text { Capturing and } \\
\text { holding both large } \\
\text { and small items are } \\
\text { impossible; the } \\
\text { additional function } \\
\text { of supporting and } \\
\text { pressing the item is } \\
\text { saved }\end{array}$ & $\begin{array}{l}\text { Roughly broken } \\
\text { walking, several } \\
\text { steps with support } \\
\text { or crutches }\end{array}$ \\
\hline 0 & $\begin{array}{l}\text { Contrasting is } \\
\text { impossible }\end{array}$ & $\begin{array}{l}\text { Fingers flexing } \\
\text { is impossible }\end{array}$ & $\begin{array}{l}\text { Capturing and } \\
\text { holding the items } \\
\text { are impossible }\end{array}$ & Doesn't go alone \\
\hline
\end{tabular}


- on the main evidential criteria the proximal and distal departments for upper and lower limbs on the level of joints have been estimated ( 2 criteria: muscle strength [5] and movements' volume [6] on generally accepted six-grades scales (Tab. 1));

- on the additional evidential criteria walking (1 criterion) and hand ( 3 criteria) have been estimated [7 with authors' correction].

The tables of the summary quantitative characteristics of movement disorders and paresis degree linked with paresis degree (Tab. 3) as well as effectiveness of motor functions restoring (Tab. 4) are also added to the Protocol.

All quantitative assessment scales have the same six-point gradation on all criteria with the same orientation from the best indicator (5 grades, no disorders) to the worst ( 0 points, plegia) linked to paresis degree: severe -1 grade, major -2 grades, moderate -3 grades, 1 mild -4 grades.

The quantitative assessment of the hand's motor functions deficit is of particular importance during a focused training of fine motor skills to restore the speech. This makes it possible to study and compare the restoration dynamics of fine motor movements of affected hand with speech restoration dynamics in motor or motor-sensory aphasia after a stroke.

The walking assessment on additional criteria (Tab. 2) is of big importance because it adds to muscle functions characteristics of affected lower limb at level of different joints such an important characteristic as walking movements coordination.

The formation of the quantitative integral assessment of motor disorders degree at level of the joints (Tab. 3) makes it possible to create a more accurate gradation of motor functions restoration and reduce the expert evaluation error in subjective assessment.

Table. 3. The summary quantitative characteristics of movement disorders depth in different parts of the upper and lower limbs

\begin{tabular}{|c|c|c|c|c|c|c|}
\hline \multicolumn{7}{|c|}{ TOTAL ASSESSMENT IN GRADES BY CRITERIA } \\
\hline \multicolumn{7}{|c|}{ Global Movements } \\
\hline \multicolumn{4}{|c|}{$\begin{array}{l}\text { Joints of upper limb departments } \\
\text { proximal: shoulder, elbow ; distal: wrist }\end{array}$} & \multicolumn{3}{|c|}{$\begin{array}{l}\text { Lower limb departments } \\
\text { proximal: hip, knee; distal: ankle }\end{array}$} \\
\hline Grades & 0 & $1-2$ & $3-4$ & $5-7$ & $8-9$ & 10 \\
\hline $\begin{array}{l}\begin{array}{l}\text { Paresis } \\
\text { degree }\end{array} \\
\end{array}$ & plegia & severe & major & moderate & mild & no disorders \\
\hline \multicolumn{7}{|c|}{$\underline{\text { Hand (including fine motor skill) }}$} \\
\hline Grades & 0 & $1-3$ & $4-6$ & $7-9$ & $10-14$ & 15 \\
\hline $\begin{array}{c}\text { Paresis } \\
\text { degree }\end{array}$ & plegia & severe & major & moderate & mild & no disorders \\
\hline \multicolumn{7}{|c|}{$\underline{\text { Walking }}$} \\
\hline Grades & 0 & 1 & 2 & 3 & 4 & 5 \\
\hline $\begin{array}{l}\begin{array}{c}\text { Paresis } \\
\text { degree }\end{array} \\
\end{array}$ & plegia & severe & major & moderate & mild & no disorders \\
\hline
\end{tabular}


The quantitative assessment of effectiveness is shown through the difference in grades before and after rehabilitation obtained at the level of limb's joint, hand or walking linked with reference to a verbal assessment (effectiveness gradation) (unchanged, minor improvements, improvements, major improvements) for two, three and one criterion according to formula $\Delta=\Delta_{2}-\Delta_{1}$, where $\Delta_{1}$ - grades before rehabilitation, $\Delta_{2}$ - grades after rehabilitation, $\Delta$ - grades difference, which shows the rehabilitation effectiveness.

The distribution of effectiveness gradations for the relevant joints, hand or walking is shown in Table 4.

Aside movement disorders also are estimated by criterion of muscle hypertone (on generally accepted Ashworth scale) [6] (Tab. 5) and by criterion of muscle hypotone (on new scale) (Tab. 6). As the muscle tone in post-stroke patients can vary from hypo to hypertonus, each with its gradation, this criterion is not included in the integral quantitative characteristics of movement disorders. Meanwhile, the quantity of hypertone and hypotone is of diagnostic value in the creation of myoneurostimulation programs of individual rehabilitation plan in patients after stroke. On the basis of the Protocol (Fig. 1) with the relevant tables (Tab. 1-6), the structural and functional model of the software module for the motor function disorders degree diagnostics in patients after stroke has been developed (Fig. 2).

The software module for the motor function disorders degree diagnostic in patients after stroke consists of a graphical interface and the objects of the program module (units): general information, motor functions assessment, instructions, database, information processing and results.

\section{Table. 4. The effectiveness of motor functions restoring}

\begin{tabular}{|c|c|c|c|}
\hline \multirow{2}{*}{$\begin{array}{c}\text { Grades of movement } \\
\text { rehabilitation effective- } \\
\text { ness }\end{array}$} & \multicolumn{3}{|c|}{ The quantity of movement rehabilitation effectiveness, } \\
\cline { 2 - 4 } & $\begin{array}{c}\text { Global Movements } \\
(2 \text { criteria })\end{array}$ & $\begin{array}{c}\text { Hand } \\
(3 \text { criteria })\end{array}$ & Walking (1 criterion) \\
\hline Major improvement & $5-10$ & $7-15$ & $3-5$ \\
\hline Improvement & $3-4$ & $4-6$ & 2 \\
\hline Minor improvement & $1-2$ & $1-3$ & 1 \\
\hline Unchanged & 0 & 0 & 0 \\
\hline
\end{tabular}

Table. 5. The muscle hypertone of the affected limb assessing

\begin{tabular}{|c|l|}
\hline Grades & \multicolumn{1}{|c|}{ Muscle hypertone reference (on the conventional Ashforth scale) } \\
\hline $\mathbf{0}$ & No changes in muscle tone \\
\hline $\mathbf{1}$ & $\begin{array}{l}\text { Slight increase in muscle tone, manifested during flexion / extension the affected } \\
\text { limb part by minimal resistance at the end of the range of motion }\end{array}$ \\
\hline $\mathbf{+ 2}$ & $\begin{array}{l}\text { Slight increase in muscle tone, manifested by resistance that appears after not less } \\
\text { than half of the range of motion performance }\end{array}$ \\
\hline $\mathbf{+ 3}$ & $\begin{array}{l}\text { Mild increase in muscle tone, manifested by through all range of motion but } \\
\text { doesn't complicate the performance of passive movements }\end{array}$ \\
\hline$+\mathbf{4}$ & $\begin{array}{l}\text { Major increase in muscle tone, which complicates performance of passive move- } \\
\text { ments }\end{array}$ \\
\hline$+\mathbf{5}$ & $\begin{array}{l}\text { Affected limb part fixed in flexion or extension - spasticity. Movements are impos- } \\
\text { sible }\end{array}$ \\
\hline
\end{tabular}


Table. 6. The muscle hypotone of the affected limb assessing

\begin{tabular}{|c|l|}
\hline Grades & \multicolumn{1}{c|}{ Muscle hypotone reference (new scale) } \\
\hline $\mathbf{0}$ & No changes in muscle tone \\
\hline $\mathbf{- 1}$ & $\begin{array}{l}\text { Slight reduction of muscle tone. Voluntary movements are possible } 75 \% \text { of norm } \\
\text { (75\% of full range of motion). The patient may hold the affected limb in a flexion } \\
\text { / extension position during passive movements. }\end{array}$ \\
\hline $\mathbf{- 2}$ & $\begin{array}{l}\text { Slight decrease in muscle tone. Voluntary movements are possible } 50 \% \text { of norm } \\
\text { (up to half of full range of motion). The patient may hold the affected limb in a } \\
\text { flexion / extension position during passive movements. }\end{array}$ \\
\hline $\mathbf{- 3}$ & $\begin{array}{l}\text { Mild decrease in muscle tone. Arbitrary Voluntary movements are possible } 25 \% \\
\text { of norm. The patient can hold the affected limb in a flexion / extension position } \\
\text { during passive movements, but for a short time. }\end{array}$ \\
\hline $\mathbf{- 4}$ & $\begin{array}{l}\text { Major decrease in muscle tone. Voluntary movements are possible } 10 \% \text { of norm. } \\
\text { The patient can't hold the affected limb in the flexion / extension position during } \\
\text { passive movements. }\end{array}$ \\
\hline $\mathbf{- 5}$ & $\begin{array}{l}\text { There is no muscle tone. Voluntary movements are impossible. The patient can't } \\
\text { hold the affected limb in the flexion / extension position during passive move- } \\
\text { ments. Atonia }\end{array}$ \\
\hline
\end{tabular}

The operator interacts directly with the Graphical user interface (GUI), which provides a dialog mode, captures motor function indicators by the testing results. The GUI also provides interconnecting and compatible functioning of software blocks.

The general information unit (Fig. 2) contains object-oriented programming (OOP) methods that introduce general patient's information according to the Protocol (Fig. 1). The information from this unit goes to the processing unit for its further storing in the buffer of processing unit and in the database.

The instructions unit contains:

- a toolkit that is the a structured, matrix-organized information for dialogue windows presenting for assessing the limbs motor function at the level of the selected joints, hand or walking, and the results of their quantitative evaluation on the PC screen;

- control codes to provide access to the toolkit for different OOP methods.

The toolkit and control codes goes from the instructions unit to the motor function assessment unit, the processing unit and results unit.

The motor function assessment unit contains OOP methods to fix by the operator the motor functions indicators of upper and lower limbs, their proximal and distal departments at the level of joints, hand and form of walking, and for transmission the fixed motor functions indicators to processing unit. This unit is functionally separated, i.e. motor functions disorders of limbs' joints, hand and form of walking are being assessed separately.

The processing unit contains a buffer for temporary storage of variables that used during program performance (which simplifies the program as a whole), methods of forming appropriate windows for assessing the motor functions, methods of forming the electronic medical record (EMR) (Fig. 2), methods for determining the paresis degree.

From the processing unit the information goes to the results unit.

The results unit presents information on the quantitative evaluation of motor functions assessment of selected limbs' joints, hand or form of walking by the criteria, and integrated quantitative assessment of its deficit and paresis degree on the PC screen. 


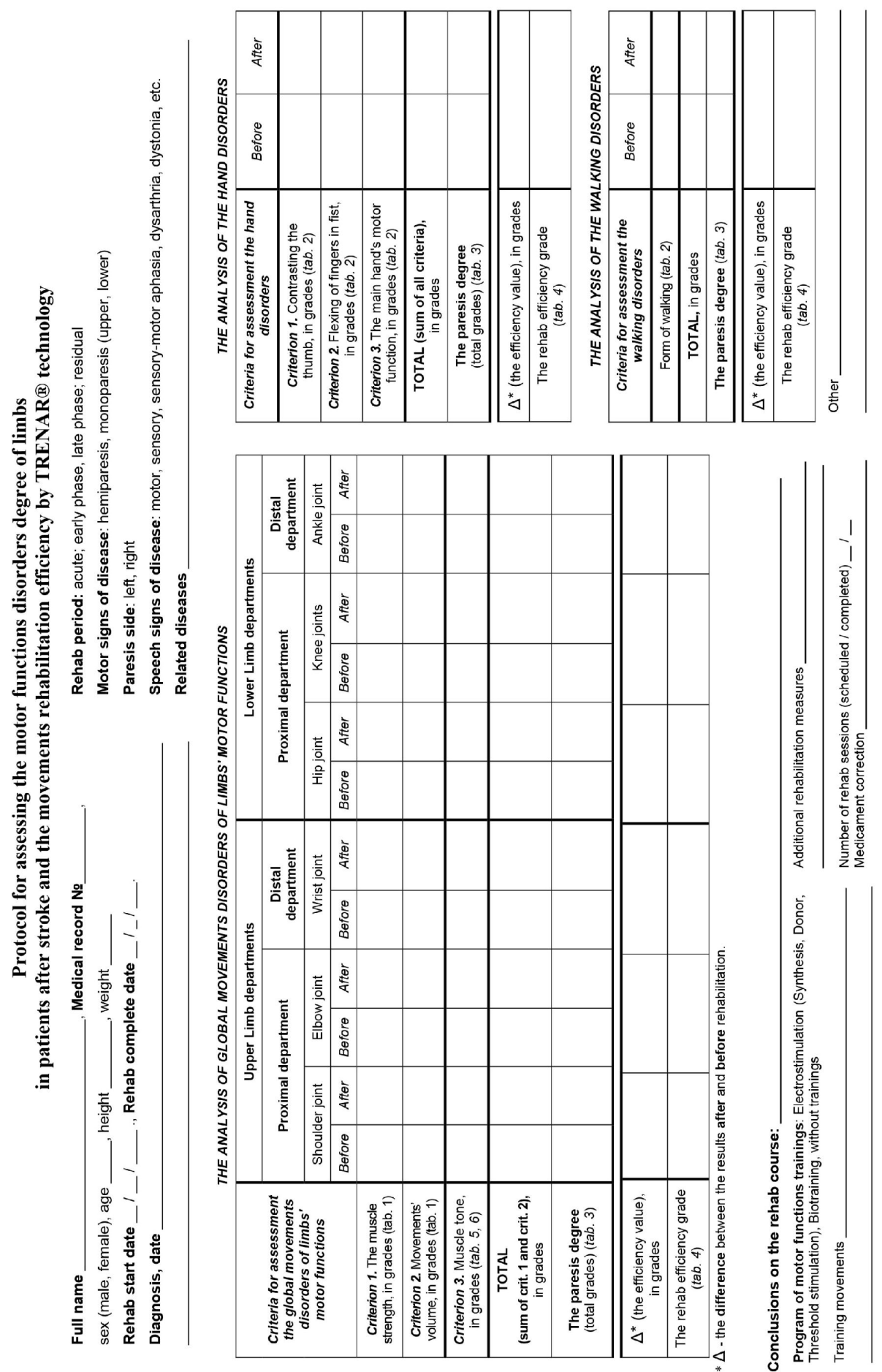

Fig. 1. Protocol for assessing the motor functions disorders degree of limbs in patients after stroke and the movements' rehabilitation efficiency by TRENAR $₫$ technology 


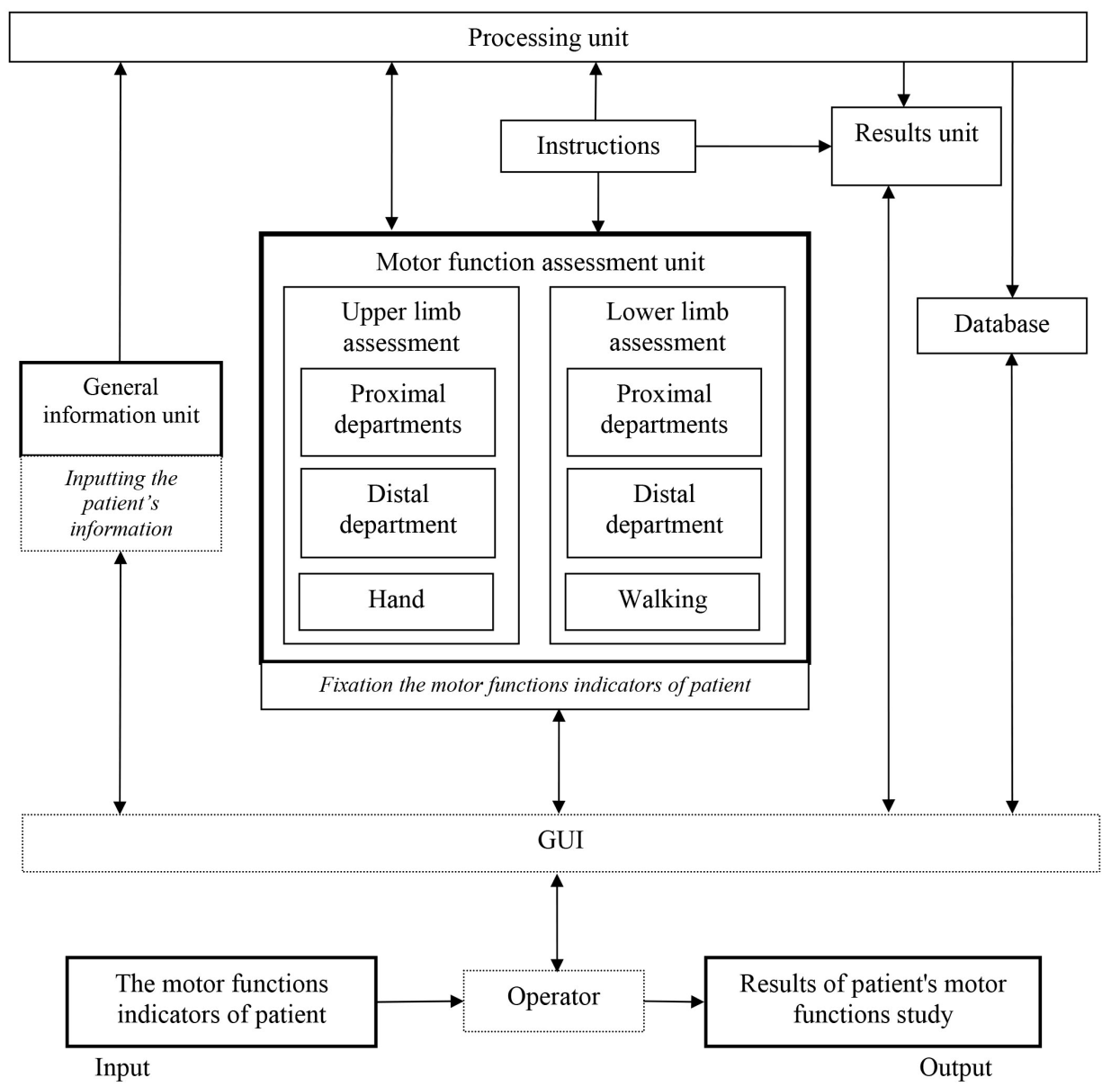

Fig. 2. Structural and functional model of the software module for the motor function disorders degree diagnostics in patients after stroke

The database is presented in the form of an electronic medical record (form 003 / o "Medical card of the in-patient"), which contains both general information about the patient and the results of the patient's motor functions testing.

\section{THE ALGORITHM FOR DIAGNOSTICS THE MOTOR FUNCTIONS DISORDER DEGREE IN PATIENTS AFTER STROKE}

The algorithm for diagnosing the motor functions disorder degree of limbs in patients after stroke (according to the technique for quantitative assessment of motor functions deficit) is presented on Fig. 3.

The software module "Movement Test Stroke", which implements this algorithm, is made in Visual Studio 2013 software environment. The programming language is C\#. It is installed in the PC structure.

The activity diagram of the software module for diagnostics the motor functions disorder degree on the basis of unified modeling language (UML) [8] is shown on Fig. 4 and consists of stages (Fig. 4): 
- Inputting the patient's information into the general information unit.

- Selecting the relevant joint, hand or walking for motor functions assessing.

- Motor functions assessing of selected joints of proximal or distal departments of upper or lower limbs; hand or form of walking according to appropriate criteria and calculation of the paresis degree.

- The diagnostics results review of motor functions disorder degree.

- Saving the diagnostics results to the electronic medical record.

- End the patient's diagnostics session.

On the diagram (Fig. 4) the nodes of solutions and associations ("diamonds", Fig. 4), which are an analog to the logical function "OR", synchronization lines, which are an analog to the logical function "AND", initial and final activity nodes (appropriately "Getting Started" and "End the Session", Fig. 4) according to the UML notation are located $[8,9]$.

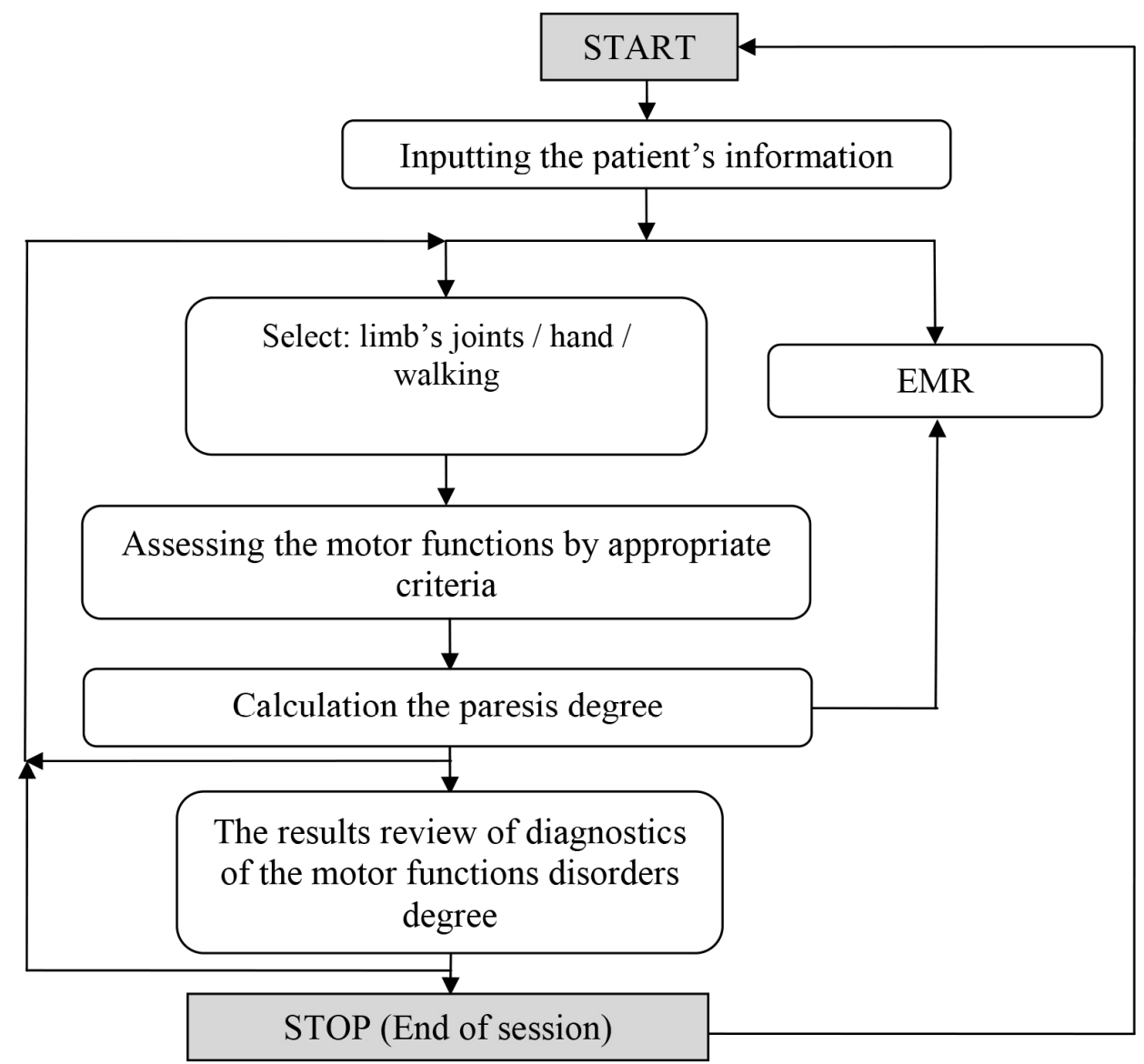

Fig. 3. Algorithm for diagnosing the motor functions disorder degree in patients after stroke 


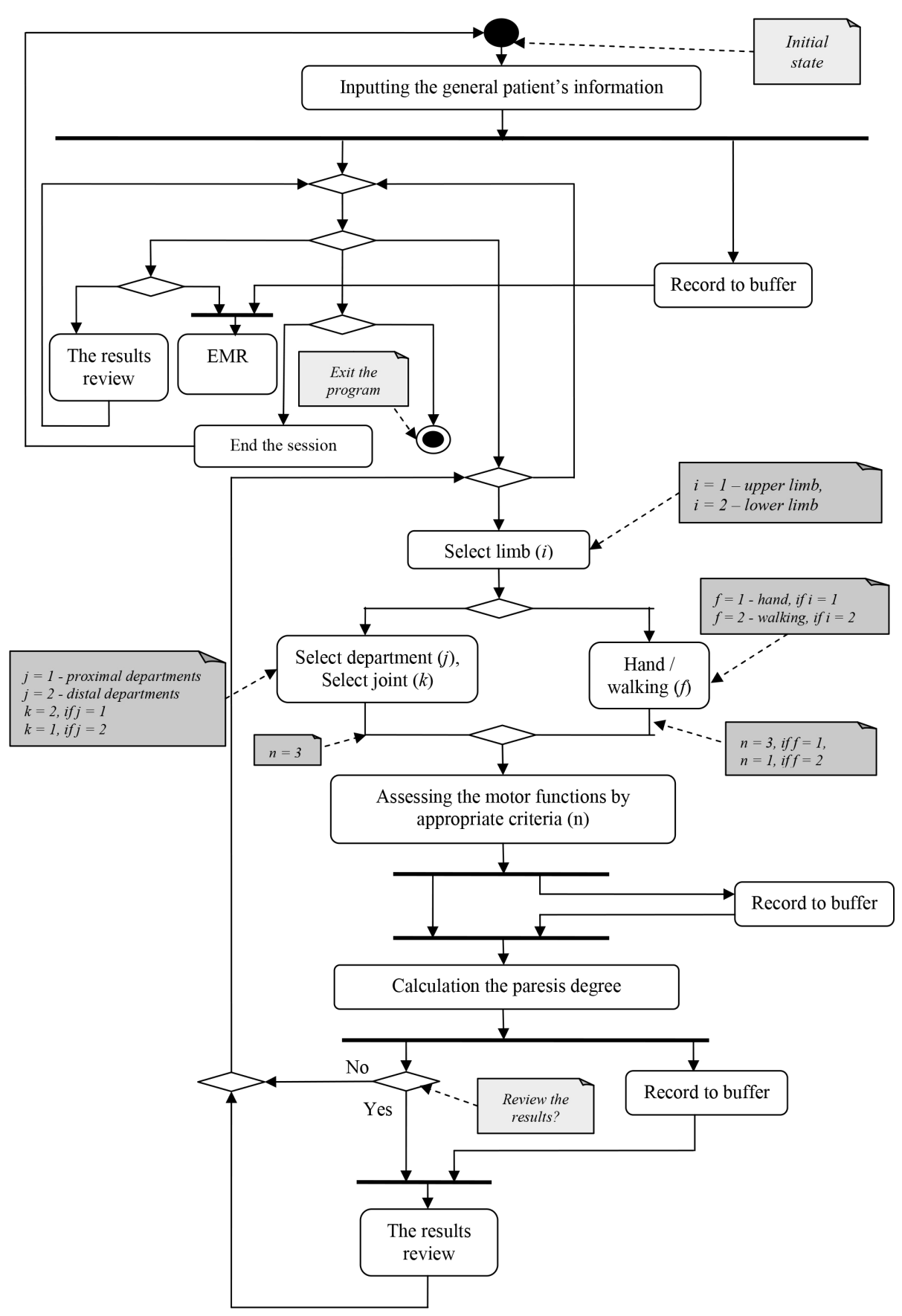

Fig. 4. Activity diagram of the software module of motor functions disorder degree diagnostics in patients after stroke 
The software consequentially implements the following actions:

1. Introduction of general patient's information. This information is stored in a buffer for future use and for storing in an electronic medical record (EMR).

2. Transition to the interface window of the motor functions assessment. The physician can carry out full testing - consequentially from the upper $(i=1)$ to lower $(i=2)$ limb, from the proximal to the distal parts, joints, and the hand or walking, however, the software module allows the separate assessment (Fig. 4).

3. The motor functions assessment. The both limbs are divided into proximal $(j=1)$ and distal departments $(j=2)$. The assessment of the proximal departments of the upper and lower limbs, which are presented by two joints $(\mathrm{k})$ on each limb: for the upper limb: $\mathrm{k}=1$ - the shoulder joint, $\mathrm{k}=2$ - the elbow joint; for the lower limb: $\mathrm{k}=1$ - the hip joint, $\mathrm{k}=2$ - knee joint, and the distal departments of upper and lower limbs, which are presented as one joint $(\mathrm{k})$ on each limb: for upper limb: wrist joint; for lower limb: ankle joint, proceeds by three criteria $(\mathrm{n}=3)$ : muscle strength, movement volume, muscle tone. The hand $(f=1)$ is being assessed by three criteria $(n=3)$, walking $(f=2)$ is being assessed by one criterion ( $\mathrm{n}=1$ ) (Fig. 4).

The interface contains tools for selecting the motor functions assessment of upper or lower limb's joints, hand or walking by relevant criteria. The windows that present descriptions of these criteria are opened using these tools, and the operator selects the necessary assessment option. If there is no selection, the program stops. The calculation of the paresis degree according to Table 3 is performed using data from the buffer on the state of the patient's motor functions in grades, which are entered by the operator in the buffer (Fig. 4). The calculation data is also stored in the buffer.

From the buffer, the results of test are displayed on the screen, where all the information on the motor functions is illustrated both by single criteria and by the total quantitative assessment of relevant joints of limbs, hand or form of walking is illustrated.

The operator can review the results after each assessing stage of assessment and decide whether enough data has already been obtained or continue working without reviewing the data. And the operator proceeds to additional assessment of limbs' motor functions at the level of the joints, hands or passages in case of insufficient data (Fig. 4).

In case of making the decision on a sufficient amount of data the operator stores them together with general patient's information in electronic medical record (EMR). A session with this patient ends (the program goes to the initial state) or the operator exits the program (Fig. 4).

The storing of motor functions testing data in electronic medical record enables one to quantify the rehabilitation effectiveness by testing at the beginning and at the end of rehabilitation course, to study the dynamics of motor functions deficit by three or more testing in one course for prediction and secondary prevention of muscle disorders, to compare the effectiveness at different stages of rehabilitation. 


\section{CONCLUSIONS}

The structural and functional model of the program module for personal diagnosing of motor functions in patients after stroke and the efficiency of motor functions restoring as a result of rehabilitation measures has been developed. An algorithm for diagnosing the motor function disorder degree of the affected limbs in patients after stroke and activity diagram of the software module in the UML notation are presented.

The software module "Movement Test Stroke" has been made in Visual Studio 2013 software environment, the programming language is C\#. The functional interaction of its components has been developed and described using Unified Modeling Language (UML). It is installed in the PC structure.

Diagnostic benefits: the ability to obtain an integral quantitative assessment of the motor functions deficit of separate joints of the upper or lower limb (by two criteria), hand (by three criteria) and walking (by one criterion) at different stages of rehabilitation, as well as a separate assessment of muscle hyper- or hypotone. It allows carrying out a detailed analysis of the motor function deficit dynamics during rehabilitation measures, to identify the specificity of disorders, to conduct a comparative assessment of individual indicators of rehabilitation efficiency.

The benefit of diagnosing is also that the assessment of motor functions disorder degree of the affected limbs is performed relative to the patient's own healthy limbs, the motor functions of which characterize the individual norm of disorders absence.

Equal six-step gradation of paresis degree, unsurpassed quantitative characteristics of motor functions rehabilitation efficiency linked to generally accepted verbal assessment of effectiveness (unchanged, minor improvements, improvements, major improvements) reduce the expert error.

The quantitative assessment of motor function deficit by evidential criteria, which is provided by the software module "Movement Test Stroke", is the basis to synthesize the digital health mobile means for information and advisory assistance to the physician in creating and making adjustments to personal plan for recovery the motor functions affected by pathology at different stages of stroke rehabilitation.

The software module "Movement Test Stroke" can be used for motor functions diagnostics not only after stroke, but also for traumatic brain injuries, brain tumors etc.

The program module enables one to evaluate the rehabilitation effectiveness and to study the dynamics of motor functions deficit for the prediction and secondary prevention of muscle disorders during course, and to compare the rehabilitation effectiveness on its different stages.

\section{REFERENCES}

1. Action Plan for Stroke in Europe 2018-2030 / Bo Norrving et al. European Stroke Journal. 2018. Vol. 3(4). P. 309-336.

2. Gritsenko V.I., Vovk M.I. Trenar - Innovative Technology of Restoration of Movements: Materials of the International Scientific and Practical Forum "Science and Business - the basis of economic development". Dnipro, 2012. P. 204-206. (in Russian).

3. Vovk M.I. Information Technology of Movement Control. Evolution of Synthesis and Development Prospects. Cybernetics and Computer Engineering. 2018. № 4 (194). P. 79-97. (in Ukrainian). 
4. Vovk M.I., Kutsiak O.A., Lauta A.D., Ovcharenko M.A. Information Support of Researches on the Dynamics of Movement Restoration After the Stroke. Cybernetics and Computer Engineering. 2017. № 3 (189). P. 61-78. (in Ukrainian).

5. Belova A., Shchepetova O. Scales, tests and questionnaires in medical rehabilitation. Moscow, 2002. 440 p. (in Russian).

6. Kadykov A., Chernikova L., Shahparonova N. Rehabilitation of neurological patients. Moscow, 2008. 560 p. (in Russian).

7. Smychek V., Ponomareva E. Craniocerebral trauma (clinic, treatment, examination, rehabilitation). Minsk, 2010. 430 p. (in Russian).

8. Buch G., Rambo D., Yakobson I. The language of the UML. User's Guide: transl. from English by N. Muhin. Moscow, 2006. 496 p. (in Russian).

9. Theory and practice of UML. Activity diagram. URL: http://it-gost.ru/articles/view_articles/96 (Last accessed: 4.06.2019). (in Russian).

\section{ЛІТЕРАТУРА}

Received 07.08.2019

1. План дій боротьби з інсультом у Свропі на 2018-2030 роки / Bo Norrving et.al. Судинні захворювання головного мозку. 2019. № 1. C. 4-32. URL: http://moz.gov.ua/uploads/ 2/12030-action_plan_for_stroke_in_europe_ukr.pdf (Дата звернення: 10.07.2019)

2. Гриценко В.И., Вовк М.И. Тренар - инновационная технология восстановления движений: Матеріали Міжнародного науково-практичного форуму «Наука і бізнес - основа розвитку економіки». Дніпро, 2012. С. 204-206.

3. Вовк М.І. Інформаційна технологія керування рухами. Еволюція синтезу і перспективи розвитку. Кибернетика и вычислительная техника. 2018. № 4 (194). С. 79-97.

4. Вовк М.І., Куцяк О.А., Лаута А.Д., Овчаренко М.А. Інформаційний супровід досліджень динаміки відновлення рухів після інсульту. Кибернетика и вычислительная техника. 2017. №3 (189). C. 61-78.

5. Белова А., Щепетова О. Шкалы, тесты и опросники в медицинской реабилитации. Москва, $2002.440 \mathrm{c}$.

6. Кадыков А., Черникова Л., Шахпаронова Н. Реабилитация неврологических больных. Москва, 2008. $560 \mathrm{c}$.

7. Смычек В., Пономарева Е. Черепно-мозговая травма (клиника, лечение, экспертиза, реабилитация). Минск, 2010. $430 \mathrm{c}$.

8. Буч Г., Рамбо Д., Якобсон И. Язык UML. Руководство пользователя: пер. с англ. Н. Мухин. Москва, 2006. 496 с.

9. Теория и практика UML. Диаграмма деятельности. URL: http:/it-gost.ru/articles/ view_articles/96 (Дата звернення: 4.06.2019)

Отримано: 07.08.2019 
M.I. Вовк, канд. біол. наук, старш. наук. співроб.,

зав. відд. біоелектричного керування та медичної кібернетики

e-mail: vovk@irtc.org.ua; imvovk3940@gmail.com

О.А. Куияк, канд. техн. наук,

старш. наук. співроб. відд. біоелектричного керування

та медичної кібернетики

e-mail: spirotech85@ukr.net

Міжнародний науково-навчальний центр інформаційних технологій

та систем НАН України та МОН України,

пр. Акад. Глушкова 40, м. Київ, 03187, Україна

\section{ПРОГРАМНИЙ МОДУЛЬ ПЕРСОНАЛЬНОЇ ДІАГНОСТИКИ РУХОВИХ ФУНКЦІЙ ПІСЛЯ ІНСУЛЬТУ}

Вступ. Діагностика рухових функцій після інсульту відіграє важливу роль у формуванні реабілітаційної програми. Результати попередньої клінічної апробації запропонованої нами методики кількісного оцінювання дефіциту рухових функцій у ході досліджень динаміки відновлення рухів на базі біоінформаційної технології керування рухами ТРЕНАР® підтвердили доцільність використання цієї методики для створення нових алгоритмічних і програмних засобів персонального діагностування рухових функцій.

Мета статті - розробити спеціалізований модуль персонального діагностування рухових функцій у хворих після інсульту, який програмно реалізує визначення ступеня порушень рухових функцій і результатів їхнього відновлення за новою методикою персонального кількісного оцінювання дефіциту рухових функцій.

Результати. Розроблено структурно-функціональну модель програмного модуля персональної діагностики рухових функцій і ефективності їхнього відновлення внаслідок реабілітаційних заходів у хворих після інсульту.

Надано алгоритм діагностики ступеня порушень рухових функцій уражених кінцівок у пацієнтів після інсульту і діаграму діяльності програмного модуля у нотації UML.

Програмний модуль "Movement Test Stroke" виконано у програмному середовищі Visual Studio 2013, мова програмування С\#. Функціональну взаємодію компонентів модуля розроблено та описано із застосуванням уніфікованої мови моделювання (UML). Модуль встановлено у структурі ПК.

Переваги діагностування: можливість отримувати інтегральну кількісну оцінку дефіциту рухових функцій верхньої та нижньої кінцівок на рівні окремих суглобів, кисті та ходи за відповідними доказовими критеріями, а також оцінку гіпер- або гіпотонусу м'язів на різних етапах реабілітації. Перевагою діагностування є й те, що оцінювання ступеня порушень рухових функцій уражених кінцівок проводиться відносно власних здорових кінцівок пацієнта, рухові функції яких характеризують індивідуальну норму відсутності порушень.

Висновки. Кількісна оцінка дефіциту рухових функцій за доказовими критеріями, яку надає програмний модуль "Movement Test Stroke", є основою синтезу мобільних засобів цифрової медицини інформаційно-консультативної допомоги лікарю у формуванні та внесенні корективів до індивідуального плану відновлення пошкоджених патологією рухових функцій на різних етапах реабілітації.

Ключові слова: програмний модуль, структурно-функиіональна модель, діагностика, алгоритм, рухові функції, персональна кількісна оцінка, інсульт. 
М.И. Вовк, канд. биол. наук, старш. науч. сотр., зав. отд. биоэлектрического управления и медицинской кибернетики e-mail:vovk@irtc.org.ua; imvovk3940@gmail.com

A.А. Куияк, канд. техн. наук, старш. науч. сотр. отд. биоэлектрического управления и медицинской кибернетики e-mail: spirotech85@ukr.net Международный научно-учебный центр информационных технологий и систем НАН Украины и МОН Украины, пр. Акад. Глушкова, 40, г. Киев, 03187, Украина

\section{ПРОГРАММНЫЙ МОДУЛЬ ПЕРСОНАЛЬНОЙ ДИАГНОСТИКИ ДВИГАТЕЛЬНЫХ ФУНКЦИЙ ПОСЛЕ ИНСУЛЬТА}

Введение. Диагностика двигательных функций после инсульта играет важную роль при формировании реабилитационной программы. Результаты предварительной клинической апробации предложенной нами методики количественной оценки дефицита двигательных функций при исследовании динамики восстановления движений на базе биоинформационной технологии управления движениями ТРЕНАР ${ }^{\circledR}$ подтвердили целесообразность использования этой методики для создания новых алгоритмических и программных средств персонального диагностирования двигательных функций.

Цель статьи - разработать специализированный модуль персонального диагностирования двигательных функций у больных после инсульта, который программно реализует определение степени нарушений двигательных функций и результатов их восстановления по новой методике персональной количественной оценки дефицита двигательных функций.

Результаты. Разработана структурно-функциональная модель программного модуля персональной диагностики двигательных функций и эффективности их восстановления в результате реабилитационных мероприятий у больных после инсульта. Представлены алгоритм диагностики степени нарушений двигательных функций пораженных конечностей у пациентов после инсульта и диаграмма деятельности программного модуля в нотации UML.

Программный модуль "Movement Test Stroke" выполнен в программной среде Visual Studio 2013, язык программирования С\#. Функциональное взаимодействие компонентов модуля разработано и описано с использованием унифицированного языка моделирования (UML). Модуль установлен в структуре ПК.

Преимущества диагностики: возможность получать интегральную количественную оценку дефицита двигательных функций верхней и нижней конечности на уровне отдельных суставов, кисти или ходьбы по соответствующим критериям, а также оценку гипер/гипотонуса мышц на различных этапах реабилитации. Преимуществом диагностирования является и то, что оценка степени нарушений двигательных функций пораженных конечностей проводится относительно собственных здоровых конечностей пациента, двигательные функции которых характеризуют индивидуальную норму отсутствия нарушений.

Выводы. Количественная оценка дефицита двигательных функций, которую обеспечивает программный модуль "Movement Test Stroke", является основой синтеза мобильных средств цифровой медицины информационно-консультативной помощи врачу в формировании и внесении коррективов в индивидуальный план восстановления поврежденных патологией двигательных функций на разных этапах реабилитации.

Ключевые слова: программный модуль, структурно-функииональная модель, диагностика, алгоритм, двигательные функиии, персональная количественная оченка, инсульт. 